\title{
Uji Daya Terima Bolu Kukus dari Tepung Kulit Singkong
}

The Acceptability of Steamed Sponge Cake Cassava Peel

\author{
${ }^{1}$ Fitri Dian Nila Sari, ${ }^{2}$ Eka Nenni Jairani \\ ${ }^{I}$ Staff Pengajar Program Studi Ilmu Gizi UNUSU, Medan, 20215, Indonesia \\ ${ }^{2}$ Staf Pengajar Program Studi Ilmu Gizi UNUSU, Medan, 20215, Indonesia \\ e-mail: ${ }^{1}$ fitridns@ymail.com, ${ }^{2}$ ekanenni_jairani@yahoo.com
}

\begin{abstract}
All this time, steamed sponge cake known and consumed by the community is just a sponge made from the main ingredients of wheat flour. In addition to the flour and the main ingredient of making steamed sponge turns cassava peel that had been thrown away just as a waste can be used as a refined ingredients sponge cake. The purpose of this research was to know the acceptability of steamed sponge cake cassava peel. The research conducted with experimental research using complete random design with four treatments by adding cassava peel flour with formulations of $100 \%, 50 \%, 20 \%$, and $0 \%$. The acceptability test of sponge cake of cassava peel against 30 panelist at Universitas Nahdlatul Ulama Sumatera Utara. Organoleptic data analysed with Mann-Whitney Test.

Based on organoleptic test on taste, smell and texture its found that panelist preferred sponge cake at treatment by adding $100 \%$ cassava peel flour. While the organoleptic test to color that panelist prefer treatment by adding $50 \%$ cassava peel flour.

It is suggested for society to utilize cassava peel flour in the manufacture of other types of food preparations and can be used snacks for all age group, include children, teenagers, adult and to elderly.
\end{abstract}

Keywords : cassava peel, flour, steamed sponge cake, organoleptic

ABSTRAK. Selama ini, bolu kukus yang dikenal dan dikonsumsi masyarakat hanyalah bolu yang terbuat dari bahan utamanya yaitu tepung terigu. Selain tepung dan bahan utama pembuatan bolu kukus, kulit singkong yang selama ini dibuang begitu saja hanya sebagai limbah, ternyata dapat dijadikan sebagai tepung bahan pembuatan bolu kukus. Adapun tujuan dari penelitian ini adalah untuk mengetahui daya terima gizi bolu kukus dari kulit singkong.

Penelitian ini merupakan penelitian eksperimen dengan rancangan acak lengkap menggunakan empat perlakuan yaitu dengan penambahan tepung kulit singkong dengan formulasi $100 \%, 50 \%, 20 \%$, dan $0 \%$. Uji daya terima bolu kukus kulit singkong dilakukan terhadap 30 orang panelis di Universitas Nahdlatul Ulama Sumatera Utara. Data uji organoleptik dianalisis dengan Mann-Whitney Test.

Berdasarkan uji organoleptik terhadap rasa, aroma, dan tekstur, diketahui bahwa panelis lebih menyukai bolu kukus dengan formulasi $100 \%$ sedangkan uji organoleptik terhadap warna panelis lebih menyukai bolu kukus dengan formulasi $50 \%$.

Disarankan kepada masyarakat agar dapat memanfaatkan tepung kulit singkong dalam pembuatan olahan makanan jenis lainnya serta dapat dijadikan sebagai jajanan untuk semua golongan umur, termasuk anak-anak, remaja, dewasa maupun untuk lanjut usia.

Kata kunci : kulit singkong, tepung, bolu kukus, organoleptik

\section{A. Pendahuluan}

Sampai saat ini kulit singkong masih belum dimanfaatkan secara optimal. Masyarakat biasanya hanya memanfaatkan kulit singkong untuk pakan ternak atau bahkan hanya dibuang, padahal kulit singkong masih mengandung zat gizi. Dalam 100 gram kulit singkong terkandung 8,11 gram protein; 15,20 gram serat kasar; 0,22 gram pektin; 1,29 gram lemak; 0,63 gram kalsium. Kulit singkong mengandung serat yang cukup tinggi yaitu 15,20 gram per 100 gram kulit singkong ${ }^{1 .}$ Serat telah lama diketahui sebagai komponen pangan yang menyehatkan pencernaan.

${ }^{2}$ Dosis letal dari HCN pada manusia ialah sekitar $60-90 \mathrm{mg}$. Secara tradisional, dikenal beberapa proses pengolahan ubi kayu untuk mengurangi kadar $\mathrm{HCN}$, antara lain dengan cara pencucian, perendaman, 
pemasakan, dan pengeringan hingga terbentuk gaplek. ${ }^{3}$ Perendaman dan perebusan yang berulang hanya dapat menghilangkan kadar $\mathrm{HCN}$ 50\% serta terjadi pengurangan kadar pati dalam ubi kayu. Cara tersebut membutuhkan waktu yang lama dan penurunan kadar HCN yang belum optimal. Salah satu cara yang dapat menurunkan kadar HCN secara optimal adalah perendaman dengan menggunakan natrium bikarbonat $\left(\mathrm{NaHCO}_{3}\right)$. ${ }^{4}$ Perendaman ubi kayu yang telah dibelah menjadi empat potongan di dalam larutan natrium bikarbonat konsentrasi 4\% mampu memengaruhi permeabilitas dinding sel sehingga senyawa HCN dapat dikeluarkan dari dalam sel.

Kulit singkong juga mengandung kadar asam biru atau asam sianida (HCN), kandungan asam sianida (HCN) dalam kulit singkong dapat dikurangi melalui beberapa perlakuan tertentu agar dapat dimanfaatkan dengan baik. ${ }^{5}$ Richana mengatakan bahwa asam sianida mudah hilang selama diproses, sianida hilang dalam perendaman, pengeringan, perebusan, dan fermentasi. Pemanfaatan kulit singkong menjadi produk makanan ini bertujuan untuk memanfaatkan limbah dari singkong dan menambah nilai gizi serat kasar pada hasil produk tersebut.

Bolu kukus adalah kue yang terbuat dari tepung terigu, gula pasir, telur ayam, air, dan emulsifier dicampur sampai mengembang kemudian diselesaikan dengan cara dikukus. Selain mengandung gizi dan serat yang baik, singkong juga dikenal bebas gluten. Pemanfaatan kulit singkong menjadi produk makanan ini bertujuan untuk memanfaatkan limbah dari singkong dan menambah nilai gizi serat kasar pada hasil produk tersebut.

\section{B. Metode Penelitian}

Metode penelitian ini menggunakan komparatif eksperimental. ${ }^{6}$ Menurut Sugiyono, penelitian eksperimen sebagai metode penelitian yang digunakan untuk mencari pengaruh perlakuan tertentu terhadap yang lain dalam kondisi yang terkendalikan. Proses pembuatan bolu kukus dari tepung kulit singkong dilaksanakan di rumah salah satu penulis, Jl. Sukarno Hatta Kota Binjai. Sedangkan pembuatan tepung kulit singkong dilakukan di Laboratorium Tata Boga UNIMED dan rumah penulis. Uji coba awal pembuatan bolu kukus dari tepung kulit singkong dilaksanakan pada bulan Juli 2017 sebanyak 2 kali. Pretest pertama dilaksanakan pada tgl 14-16 Juli 2017 dan pretest kedua pada tgl 25-27 Juli 2017. Kemudian penelitian eksperimen itu sendiri dilakukan pada Maret s/d Juli 2018. Penilaian data subyektif atau warna, rasa, aroma, tekstur dilakukan dengan uji hedonik pada 30 orang panelis di Universitas Nahdlatul Ulama Sumatera Utara.

Penilaian subyektif yang digunakan dalam uji daya bolu kukus dari kulit singkong adalah uji organoleptik jenis uji hedonik. Uji hedonik/ uji kesukaan merupakan salah satu uji penerimaan dalam uji ini panelis diminta mengungkapkan tanggapan pribadinya tentang kesukaan atau ketidaksukaannya. Karakteristik pengujian organoleptik adalah penguji cenderung melakukan penilaian berdasarkan kesukaan, penguji tanpa melakukan latihan, penguji umumnya tidak melakukan penginderaan berdasarkan kemampuan seperti dalam pengujian inderawi, pengujian dilakukan di tempat terbuka sehingga diskusi kemungkinan terjadi ${ }^{7}$. Pada waktu melakukan uji kesukaan ini digunakan tingkat kesukaan panelis terhadap sampel. Pengujian organoleptik ini menggunakan lima kategori kesukaan dan diberi skor. Kriteria penilaian berupa : sangat suka skor 4, suka skor 3, kurang suka skor 2, dan tiidak suka skor 1

Data yang sudah dikumpulkan, diolah secara manual kemudian dianalisis dengan menggunakan analisis deskriptif persentase. Analisis deskriptif persentase ini digunakan untuk mengkaji reaksi panelis terhadap suatu bahan yang diujikan.Untuk mengetahui tingkat kesukaan dari panelis dilakukan analisis deskriptif kualitatif persentase yaitu kualitatif yang diperoleh dari panelis harus dianalisis dahulu untuk dijadikan data kuantitatif.

Tabel 1. Interval Persentase dan Kriteria Kesukaan

\begin{tabular}{|l|l|}
\hline Persentase $(\%)$ & Kesukaan \\
\hline $100-81$ & Sangat suka \\
\hline $80-61$ & Suka \\
\hline $60-41$ & Kurang suka \\
\hline $40-21$ & Tidak suka \\
\hline
\end{tabular}

Setelah mengetahui bagaimana penerimaan panelis terhadap bolu kukus dari tepung kulit singkong yang dihasilkan, maka langkah selanjutnya adalah mengetahui ada atau tidaknya perbedaan pada organoleptik bolu kukus dari tepung kulit singkong, maka dapat dilakukan analisis data dengan menggunakan uji MannWhitney dengan tingkat signifikan 0,05 karena data tidak berdistribusi normal ( $<<0,05)$. Jika dari uji MannWhitney nilai $\mathrm{p}>0,05$ maka Ho diterima berarti tidak adanya perbedaan daya terima dari masing-masing perlakuan.

\section{Hasil Penelitian dan Pembahasan}

Hasil uji organoleptik bolu kukus dari tepung kulit singkong terhadap warna bolu kukus yang telah dilakukan oleh 30 orang panelis dapat dilihat dari tabel berikut: 
Tabel 2. Hasil Analisis Organoleptik Bolu Kukus Tepung Kulit Singkong terhadap Warna

\begin{tabular}{|c|c|c|c|c|c|c|c|c|c|c|c|}
\hline \multirow{3}{*}{ No } & \multirow{3}{*}{ Formulasi } & \multicolumn{10}{|c|}{ Distribusi Frekuensi } \\
\hline & & \multicolumn{2}{|c|}{4} & \multicolumn{2}{|c|}{3} & \multicolumn{2}{|c|}{2} & \multicolumn{2}{|c|}{1} & \multicolumn{2}{|c|}{ Total } \\
\hline & & $\mathrm{f}$ & $\%$ & f & $\%$ & $\mathrm{f}$ & $\%$ & $\mathrm{f}$ & $\%$ & Skor & $\%$ \\
\hline 1 & $100 \% \mathrm{KS}$ & 9 & 30 & 17 & 56,7 & 4 & 13,3 & & & 95 & 25,4 \\
\hline 2 & $50 \% \mathrm{KS}$ & 7 & 23,3 & 22 & 73,3 & 1 & 3,3 & & & 96 & 25,7 \\
\hline 3 & $20 \% \mathrm{KS}$ & 5 & 16,6 & 21 & 70 & 4 & 13,3 & & & 91 & 24,3 \\
\hline 4 & $0 \% \mathrm{KS}$ & 5 & 16,6 & 22 & 73,3 & 3 & 10 & & & 92 & 24,6 \\
\hline
\end{tabular}

Berdasarkan tabel di atas diidapatkan bahwa dari aspek warna bolu kukus dengan formulasi $50 \%$ tepung kulit singkong memiliki skor tertinggi yaitu $96(25,7 \%)$ sedangkan skor terendah yaitu pada bolu kukus dengan formulasi $20 \%$ tepung kulit singkong sebesar 91 (24,3\%). Dari total skor tersebut menunjukkan bahwa panelis lebih menyukai warna bolu kukus dengan formulasi 50\% tepung kulit singkong.

Warna adalah corak yang sukar diukur sehingga menimbulkan pendapat yang berlainan dalam menilai kualitas warnanya. Perbedaan warna disebabkan setiap orang memiliki perbedaan penglihatan, meskipun mereka dapat membedakan warna namun setiap orang memiliki kesukaan yang berbeda.

Fungsi warna pada suatu makanan sangatlah penting, karena dapat membangkitkan selera. Warna makanan yang menarik dapat mempengaruhi dan meningkatkan selera makan pada konsumen, bahkan warna dapat menjadi petunjuk bagi kualitas makanan yang dihasilkan. Warna juga mempunyai peran dan arti pada pangan karena dapat mempengaruhi penerimaan konsumen pada pangan tersebut. Bila suatu makanan menyimpang dari warna yang umumnya berlaku, makanan tersebut pastinya tidak dipilih oleh konsumen, walaupun sesungguhnya makanan tersebut masih baik kondisinya. Meskipun demikian, warna juga tidak selalu identik dengan suatu rasa tertentu ${ }^{8}$.

Suka atau tidaknya suka panelis terhadap bolu kukus dari tepung kulit singkong dapat dipengaruhi oleh tertarik atau tidak tertariknya panelis terhadap warna yang dihasilkan bolu kukus tersebut. Uji daya terima bolu kukus terhadap warna oleh panelis menunjukkan bahwa bolu kukus dari 50\% tepung kulit singkong memiliki skor tertinggi yaitu 96 (25,7\%) sedangkan skor terendah yaitu pada bolu kukus dengan formulasi $20 \%$ tepung kulit singkong sebesar 91 (24,3\%). Dari total skor tersebut menunjukkan bahwa panelis lebih menyukai warna bolu kukus dengan formulasi $50 \%$ tepung kulit singkong. Akan tetapi, keempat perlakuan bolu kukus tersebut sama-sama dikategorikan ke dalam kategori sangat suka karena masih berada dalam interval persentase (100 81).

Tingginya skor pada formulasi bolu kukus dengan 50\% tepung kulit singkong disebabkan para panelis menyulai warna khas bolu kukus yang coklat karena adanya gula merah dan coklat bubuk sebagai bahan baku bolu kukus. Selama pengukusan terjadi proses pencoklatan Maillard dari laktosa dalam susu yang digunakan dan kandungan lisin pada tepung kedelai. Namun reaksi pencoklatan tersebut menurun karena kandungan pati dalam tepung lebih tinggi daripada lisin. Kandungan pati yang ada dalam tepung akan berkontribusi terhadap penyerapan air dan hal tersebut akan mempengaruhi proses Maillard yang terjadi selama pemanggangan.

Hal tersebut sesuai dengan penelitian sebelumnya bahwa dampak kecerahan dari suatu produk dapat dipengaruhi oleh beberapa hal, seperti adanya distribusi air, yang dapat memberikan dampak pada reaksi pencoklatan Maillard dan karamelisasi, sehingga semakin tinggi kandungan air dan adanya pengenceran bahan maka reaksi pencoklatan akan semakin berkurang 9,10

b. Uji Organoleptik Bolu Kukus dari Tepung Kulit Singkong terhadap Aroma

Hasil uji organoleptik bolu kukus dari tepung kulit singkong terhadap aroma bolu kukus yang telah dilakukan oleh 30 orang panelis dapat dilihat dari tabel berikut:

Tabel 3. Hasil Analisis Organoleptik Bolu Kukus Tepung Kulit Singkong terhadap Aroma

\begin{tabular}{|c|c|c|c|c|c|c|c|c|c|c|c|}
\hline \multirow{3}{*}{ No } & \multirow{3}{*}{ Formulasi } & \multicolumn{10}{|c|}{ Distribusi Frekuensi } \\
\hline & & \multicolumn{2}{|c|}{4} & \multicolumn{2}{|c|}{3} & \multicolumn{2}{|c|}{2} & \multicolumn{2}{|c|}{1} & \multicolumn{2}{|c|}{ Total } \\
\hline & & $\mathrm{f}$ & $\%$ & $\mathrm{f}$ & $\%$ & $\mathrm{f}$ & $\%$ & $\mathrm{f}$ & $\%$ & Skor & $\%$ \\
\hline 1 & $100 \% \mathrm{KS}$ & 4 & 13,3 & 21 & 70 & 5 & 16,6 & & & 89 & 25,4 \\
\hline 2 & $50 \% \mathrm{KS}$ & 3 & 10 & 22 & 73,3 & 5 & 16,6 & & & 88 & 25,1 \\
\hline 3 & $20 \% \mathrm{KS}$ & 3 & 10 & 21 & 70 & 5 & 16,6 & 1 & 3,3 & 86 & 24,6 \\
\hline 4 & $0 \% \mathrm{KS}$ & 2 & 6,6 & 25 & 83,3 & 1 & 3,3 & 2 & 6,6 & 87 & 21,9 \\
\hline
\end{tabular}

Berdasarkan tabel di atas diidapatkan bahwa dari aspek aroma bolu kukus dengan formulasi $100 \%$ tepung kulit singkong memiliki skor tertinggi yaitu $89(25,4 \%)$ sedangkan skor terendah yaitu pada bolu kukus 
dengan formulasi 100\% tepung kulit singkong sebesar 87 (21,9\%). Dari total skor tersebut menunjukkan bahwa panelis lebih menyukai aroma bolu kukus dengan formulasi $100 \%$ tepung kulit singkong.

Aroma merupakan bau khas yang dihasilkan oleh suatu makanan dan dinilai subjektif oleh indera penciuman. Bahan makanan umumnya dapat dikenali dengan mencium aromanya. Aroma mempunyai peranan yang sangat penting dalam penentuan derajat penilaian dan kualitas suatu bahan pangan, seseorang yang menghadapi makanan baru, maka selain bentuk dan warna, bau atau aroma akan menjadi perhatian utamanya sesudah bau diterima maka penentuan selanjutnya adalah cita rasa disamping teksturnya. Menurut wheat (1981), aroma adalah bau yang sukar diukur sehingga menimbulkan pendapat yang berlainan dalam menilai kualitas $\operatorname{aromanya}^{11}$.

Perbedaan pendapat ini disebabkan karena setiap orang memiliki perbedaan penciuman, meskipun mereka dapat membedakan aroma namun setiap orang mempunyai kesukaan yang berlainan. Uji daya terima bolu kukus terhadap bolu kukus menunjukkan bahwa aroma bolu kukus dengan formulasi 100\% tepung kulit singkong memiliki skor tertinggi yaitu $89(25,4 \%)$ sedangkan skor terendah yaitu pada bolu kukus dengan formulasi 100\% tepung kulit singkong sebesar 87 (21,9\%). Dari total skor tersebut menunjukkan bahwa panelis lebih menyukai aroma bolu kukus dengan formulasi 100\% tepung kulit singkong. Dari total skor tersebut menunjukkan bahwa panelis lebih menyukai aroma bolu kukus dengan formulasi $100 \%$ tepung kulit singkong. Akan tetapi, keempat perlakuan bolu kukus tersebut sama-sama dikategorikan ke dalam kategori sangat suka karena masih berada dalam interval persentase $(100-81)$.

c. Uji Organoleptik Bolu Kukus dari Tepung Kulit Singkong terhadap Rasa

Hasil uji organoleptik bolu kukus dari tepung kulit singkong terhadap rasa bolu kukus yang telah dilakukan oleh 30 orang panelis dapat dilihat dari tabel berikut:

Tabel 4. Hasil Analisis Organoleptik Bolu Kukus Tepung Kulit Singkong terhadap Rasa

\begin{tabular}{|c|c|c|c|c|c|c|c|c|c|c|c|}
\hline \multirow{3}{*}{ No } & \multirow{3}{*}{ Formulasi } & \multicolumn{10}{|c|}{ Distribusi Frekuensi } \\
\hline & & \multicolumn{2}{|c|}{4} & \multicolumn{2}{|c|}{3} & \multicolumn{2}{|c|}{2} & \multicolumn{2}{|c|}{1} & \multicolumn{2}{|c|}{ Total } \\
\hline & & $\mathrm{f}$ & $\%$ & $\mathrm{f}$ & $\%$ & $\mathrm{f}$ & $\%$ & $\mathrm{f}$ & $\%$ & Skor & $\%$ \\
\hline 1 & $100 \% \mathrm{KS}$ & 7 & 23,3 & 16 & 53,3 & 7 & 23,3 & & & 90 & 26,5 \\
\hline 2 & $50 \% \mathrm{KS}$ & 2 & 6,6 & 20 & 66,6 & 8 & 26,6 & & & 84 & 24,8 \\
\hline 3 & $20 \% \mathrm{KS}$ & 2 & 6,6 & 20 & 66,6 & 8 & 26,6 & & & 84 & 24,8 \\
\hline 4 & $0 \% \mathrm{KS}$ & 2 & 6,6 & 19 & 63,3 & 7 & 23,3 & 2 & 6,6 & 81 & 23,9 \\
\hline
\end{tabular}

Berdasarkan tabel di atas diidapatkan bahwa dari aspek rasa bolu kukus dengan formulasi 100\% tepung kulit singkong memiliki skor tertinggi yaitu 90 (26,5\%) sedangkan skor terendah yaitu pada bolu kukus dengan formulasi $0 \%$ tepung kulit singkong sebesar $81(23,9 \%)$. Dari total skor tersebut menunjukkan bahwa panelis lebih menyukai rasa bolu kukus dengan formulasi $100 \%$ tepung kulit singkong.

Rasa timbul akibat adanya rangsangan kimiawi yang dapat diterima oleh indera pencicip atau lidah. Rasa adalah faktor yang mempengaruhi penerimaan produk pangan. Jika aroma, warna dan tekstur baik tetapi konsumen tidak menyukai rasanya maka konsumen tidak akan menerima produk pangan tersebut ${ }^{12}$.

Penilaian rasa bolu kukus dari tepung kulit singkongmerupakan penilaian subjektif oleh panelis berdasarkan indera pengecap. Penilaian suka atau tidak suka terhadap rasa bolu kukus didasarkan pada enak atau tidaknya bolu kukus sesuai dengan selera masing-masing. Bolu kukus terasa manis karena dalam bahan baku pembuatan bolu tersebut terdapat gula merah..

Uji daya terima bolu kukus terhadap bolu kukus menunjukkan bahwa rasa bolu kukus dengan formulasi 100\% tepung kulit singkong memiliki skor tertinggi yaitu 90 (26,5\%) sedangkan skor terendah yaitu pada bolu kukus dengan formulasi 100\% tepung kulit singkong sebesar 81 (23,9\%). Dari total skor tersebut menunjukkan bahwa panelis lebih menyukai rasa bolu kukus dengan formulasi $100 \%$ tepung kulit singkong. Dari total skor tersebut menunjukkan bahwa panelis lebih menyukai rasa bolu kukus dengan formulasi $0 \%$ tepung kulit singkong. Akan tetapi, keempat perlakuan bolu kukus tersebut sama-sama dikategorikan ke dalam kategori sangat suka karena masih berada dalam interval persentase $(100-81)$.

d. Uji Organoleptik Bolu Kukus dari Tepung Kulit Singkong terhadap Tekstur

Hasil uji organoleptik bolu kukus dari tepung kulit singkong terhadap tekstur bolu kukus yang telah dilakukan oleh 30 orang panelis dapat dilihat dari tabel berikut:

Tabel 5. Hasil Analisis Organoleptik Bolu Kukus Tepung Kulit Singkong terhadap Tekstur

\begin{tabular}{|c|c|c|c|c|c|c|c|c|c|c|c|}
\hline \multirow{3}{*}{ No } & \multirow{3}{*}{ Formulasi } & \multicolumn{10}{|c|}{ Distribusi Frekuensi } \\
\hline & & \multicolumn{2}{|c|}{4} & \multicolumn{2}{|c|}{3} & \multicolumn{2}{|c|}{2} & \multicolumn{2}{|c|}{1} & \multicolumn{2}{|c|}{ Total } \\
\hline & & $\mathrm{f}$ & $\%$ & $\mathrm{f}$ & $\%$ & $\mathrm{f}$ & $\%$ & $\mathrm{f}$ & $\%$ & Skor & $\%$ \\
\hline 1 & $100 \% \mathrm{KS}$ & 6 & 20 & 12 & 40 & 11 & 36,6 & 1 & 3,3 & 83 & 26,9 \\
\hline 2 & $50 \% \mathrm{KS}$ & 3 & 10 & 16 & 53,3 & 9 & 30 & 2 & 6,6 & 80 & 26 \\
\hline 3 & $20 \% \mathrm{KS}$ & 2 & 6,6 & 12 & 40 & 11 & 36,6 & 5 & 16,6 & 71 & 23,1 \\
\hline
\end{tabular}


Berdasarkan tabel di atas diidapatkan bahwa dari aspek tekstur bolu kukus dengan formulasi $100 \%$ tepung kulit singkong memiliki skor tertinggi yaitu $83(26,9 \%)$ sedangkan skor terendah yaitu pada bolu kukus dengan formulasi $20 \%$ tepung kulit singkong sebesar $71(23,1 \%)$. Dari total skor tersebut menunjukkan bahwa panelis lebih menyukai tekstur bolu kukus dengan formulasi $100 \%$ tepung kulit singkong.

Penilaian tekstur suatu produk makanan merupakan penilaian berdasarkan indera peraba. Tekstur makanan berkaitan dengan sensasi sentuhan. Memandang suatu produk dapat memberi gagasan apakah suatu produk tersebut kasar, halus, keras, atau lembek ${ }^{13}$. Tekstur merupakan tekanan yang dapat diamati dengan mulut (pada waktu digigit, dikunyah dan ditelan) ataupun peraba dengan jari.

Pengujian terhadap tekstur bolu kukus oleh panelis menunjukkan bahwa panelis paling menyukai tekstur bolu kukus dengan formulasi $100 \%$ dengan skor $83(26,9 \%)$ sedangkan skor terendah yaitu pada bolu kukus dengan formulasi 20\% tepung kulit singkong sebesar 71 (23,1\%). Dari total skor tersebut menunjukkan bahwa panelis lebih menyukai tekstur bolu kukus dengan formulasi 100\% tepung kulit singkong. Dari total skor tersebut menunjukkan bahwa panelis paling menyukai tekstur bolu kukus dengan formulasi $100 \%$ tepung kulit singkong. Akan tetapi, keempat perlakuan bolu kukus tersebut sama-sama dikategorikan ke dalam kategori sangat suka karena masih berada dalam interval persentase $(100-81)$.

Tekstur pada bolu kukus dengan formulasi tepung kulit singkong $0 \%$ menghasilkan tekstur bolu kukus yang lembut dan merekah. Sedangkan pada bolu kukus dengan formulasi tepung kulit singkong $100 \%$ menghasilkan tekstur bolu kukus yang lembut juga namun lebih padat dan tidak merekah. Hal ini disebabkan karena tepung kulit singkong yang dipergunakan sebagai bahan merupakan tepung mocaf yang bebas gluten dan memiliki tekstur yang susah mengembang.

Tekstur dan konsistensi suatu bahan akan mempengaruhi cita rasa yang ditimbulkan bahan tersebut karena dapat mempengaruhi kecepatan timbulnya rangsangan terhadap sel reseptor olfaktori dan kelenjar air liur. Semakin kental suatu bahan, penerimaan terhadap intensitas rasa, bau, dan cita rasa semakin berkurang ${ }^{14}$.

\section{Kesimpulan}

Berdasarkan hasil penelitian yang telah dilakukan, diperoleh kesimpulan sebagai berikut :

1. Berdasarkan uji organoleptik terhadap rasa, aroma, dan tekstur, diketahui bahwa panelis lebih menyukai bolu kukus dengan formulasi $100 \%$ tepung kulit singkong sedangkan uji organoleptik terhadap warna panelis lebih menyukai bolu kukus dengan formulasi $50 \%$.

2. Dari keempat formulasi bolu kukus dari kulit singkong dari aspek warna, rasa, aroma, dan tektur menunjukkan bahwa keempat perlakuan bolu kukus tersebut sama-sama dikategorikan ke dalam kategori sangat suka karena masih berada dalam interval persentase $(100-81)$.

\section{E. Daftar Pustaka}

[1] Rukmana, R. 1997. Ubi Kayu: Budi Daya Pascapanen. Kanisius, Yogyakarta.

[2] Muhlisin, A. 2014. Keracunan Singkong. http://mediskus.com/penyakit/keracunan-singkong.html. 30 Agustus 2014.

[3] Purawisastra, S. 2001. Detoksifikasi dan Peningkatan Kadar Protein Singkong Pahit. Badan Litbang Kesehatan. http://digilib.litbang.depkes.go.id. 20 Juni 2015.

[4] Hutami, F.D dan Harijono. 2014. Pengaruh Penggantian Larutan dan Kosentrasi NaHCO3 terhadap Penurunan Kadar HCN pada Pengelolahan Tepung Ubi Kayu. Jurnal Pangan dan Argoindustri, 2(4) : 220-230.

[5] Richana,N, dkk. 2012. Budidaya Singkong. ITB. Bandung.

[6] Sugiyono, 2013. Statistika untuk Penelitian. Alfabeta. Bandung.

[7] Kartika, B., P. Hastuti dan W. Supartono. 1988. Uji Inderawi Bahan Pangan. Pusat Antar Universitas Pangan dan Gizi. Universitas Gadjah Mada, Yogyakarta.

[8] Astawan, M. 2008. Khasiat Warna Warni Makanan. PT. Gramedia Pustaka Utama. Jakarta.

[9] Mezaize, S. Chevallier, A. Le-Bail and M. de Lamballerie. 2010. Gluten-free Frozen Dough: Influence of Freezing on Dough Theological Properties and Bread Quality, Food Research International, 43, 8, (2186).

[10] Mohammadi S, Subramaniam S, Grama A. 2013. Inferring the Effective TOR-Dependent Network: a Computational Study in Yeast. BMC Syst Biol 7:84

[11] Grace, Y. 2016. Daya Terima Bubur Bayi Instan Dengan Penambahan Umbi Bit (Beta Vulgaris L.) Serta Kandungan Zat Gizi. Universitas Sumatera Utara. Medan. Skripsi.

[12] Rahmawan, W. S. 2006. Pemanfaatan Potensi Tepung Ubi Jalar dan Pati Garut Sebagai Bahan Substitusi Tepung Terigu dalam Pembuatan Cookies yang Diperkaya Isolat Protein Kedelai Untuk 
Intervensi Gizi. Skripsi Fakultas Pertanian Program Studi Gizi Masyarakat dan Sumberdaya Keluarga. Institut Pertanian Bogor. Bogor.

[13] Shewfelt, R. 2013. Pengantar Ilmu Pangan. Jakarta: Penerbit Buku Kedokteran EGC.

[14] Winarno, F.G. 2007. Kimia Pangan dan Gizi. Gramedia Pustaka Utama. Jakarta. 